\section{THE PRODUCTIVITY AND COMPETITIVENESS PROBLEMS OF LATVIA IN THE CONTEXT OF THE GLOBAL ECONOMY}

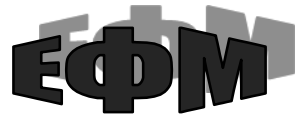

http://efm.vsau.org/

In the article the dynamics of labour productivity in Latvia was analyzed and the factors which have influenced the labour productivity in last 5 years were detected, to compare the productivity in Latvia with EU average. Analysing changes in productivity and labour costs in Latvia from 2013 till 2017, we can see that growth of labour costs exceeds the growth of productivity by more than 2 times in both, tradable sector and total economy. Slow growth in productivity compared with the labour and other production expenses lead to an increase in the price of final goods and services, which negatively corresponds with producers' competitiveness in both internal and external market. Also, the attention is focused on how to increase productivity growth potential and improve the competitiveness of Latvia. One of the main challenges for Latvia is the creation of new competitive advantages that are associated with investments in the latest technologies, innovation, research, human capital, efficient allocation of resources and redistribution that comes with the behavioural changes of economic subjects.

The main conclusion of the research shows, that two mutually interconnected processes determine increase of productivity level. First, they are the entrepreneurs' choices about competitive advantages on which their business strategies are based, which define the business management and technological decisions (to modernize production or to move resources across sectors, to other region or even other country). Second, it is the ability of the country to ensure the reallocation of its resources to the most productive firms and sectors, i.e. to promote structural reforms or "technological upgrading".

Key words: labour productivity, labour costs, production expenses, economic growth, competitiveness.

Fig.: 3. Lit.: 10.

Setting the problem. Productivity is the main factor for Latvia to increase prosperity, ensuring efficient use of resources. Due to limited availability of resources and the increasing competition in the global markets, it is important for Latvia to support its economic growth through increased productivity. The integration of the country in the EU Single Market had a positive impact on the productivity dynamics strengthening economic growth and accelerating the convergence process, however, in comparison with several developed countries of the EU, the productivity gap is comparatively large. In 2017, the productivity level in Latvia was only $46.8 \%$ (68\% according to PPS) of the EU average [3].

Productivity is close related to competitiveness. At the World Economic Forum (WEF) experts by developing Global Competitiveness Index (GCI), defines competitiveness as productivity [10, p.2]. WEF experts believe that welfare and life quality level are defined by the productivity level, which depends on possibility to mobilize all resources in Economy. Productivity allows country to sustain high level of salaries, stabile and strong national currency and high level of capital return, and by them also high level of life standards.

○ JEKABSONE SANDRA, 2019 


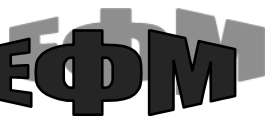

http://efm.vsau.org/

After the global financial crisis, the model of economic growth in Latvia has changed, the economy has become more stable and balanced as a result of macroeconomic adjustments and decreasing internal and external proportions. Nevertheless, in the rankings of competitiveness which are regularly published by WEF, Latvia significantly lags behind other recent EU countries (the Czech Republic, Poland, Slovenia, Slovakia and the other Baltic States), and particularly in indicators related to the development of innovation systems [4, $\mathrm{p}$. 924-925]. This is mostly because manufacturing is a small proportion of Latvian GDP and because of the industrial sub-sector's technological structure, where low technology industries are dominating (they amount to $60 \%$ of total manufacturing added value), altogether this is why there is such low level of productivity in manufacturing and in whole national economy.

Analysis of recent research and publications. Term of productivity is a multidimensional and its definition might change according different situations. OECD, IMF, World Bank, the European Commission in various publications (such as: [1], [6], [9]) deal different aspects of productivity. Productivity generally refers to the relation between the quantity of production produced (output) and the quantity of resources (production factors) used in the production process [5, p.93]. In a small and open economy, productivity in the country (at macro level) is determined mainly by the average benefit of exported production per worker. It is export goods that determine the country's competitiveness on international markets, which leads us to question, does or economy gain profit because of high technology or we gain profit because of cheap labour force [7, 681-682]. If productivity is high, teachers and hairdressers will have high income. If this implication is not complied, than in the internal demand-driven sectors (mainly service sectors), wages are growing faster, there is inflation, loss of competitiveness and exports shrink.

In The World Economic Forum research "Readiness for the Future of Production Report 2018 " is determined that country readiness to future challenges set by the current production base, its structure, as well as the development level of main drivers (including technologies and innovations, human capital, participation in international trade, quality of institutional system etc.) [8].

Defining the aim of the article. The aim of the research is to appreciate the dynamics of labour productivity and the level of productivity between Latvia and EU average, as well as to assess the potential for productivity growth to improve competitiveness of Latvia.

Presentation of the main results of the research. Productivity growth rates in Latvia are also among the highest in the EU. Since 2011, they have grown by $14.7 \%$ (by $4 \%$ in EU28 ) as a result productivity gap has decreased for 9\% points with EU average level. In 2017 productivity in overall Latvian economy, described as GDP per person employed reached $46.8 \%$ of average EU level (See Fig. 1).

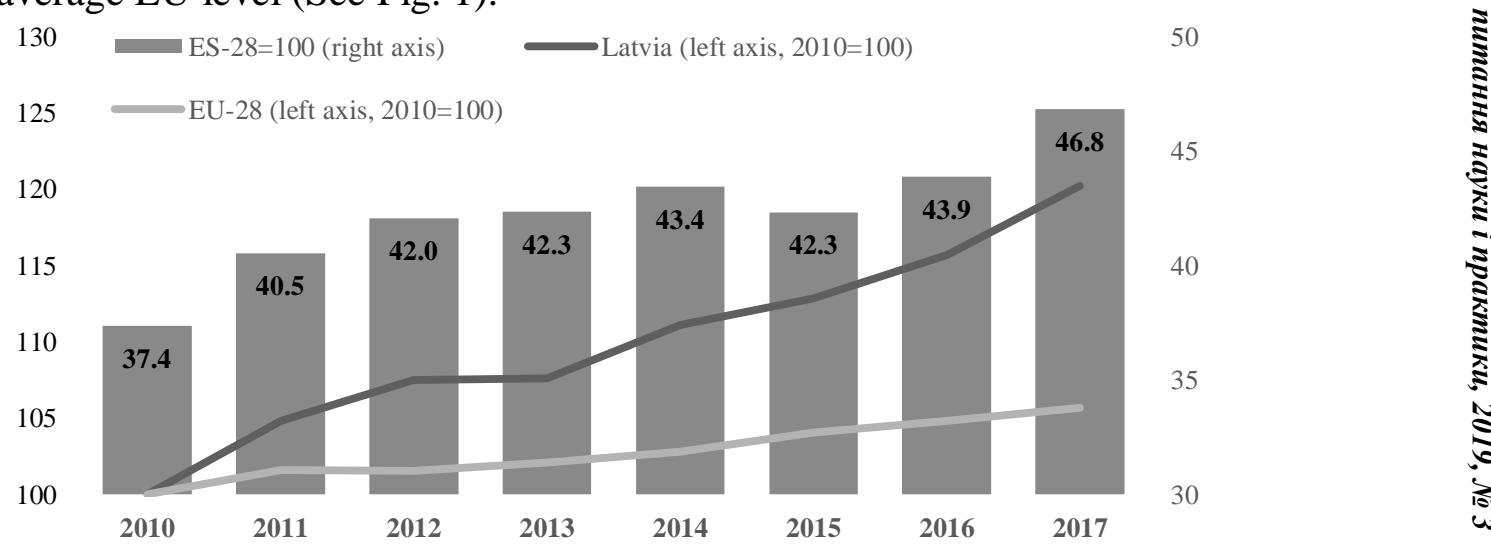

Fig. 1. Productivity Changes in Latvia and EU

Source: constructed by the author using [3] 


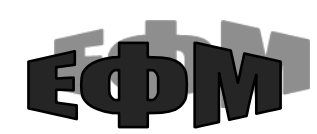

http://efm.vsau.org/

Although Latvia is in one of the leading positions by productivity growth rates among the EU Member States, yet wages have been growing faster than productivity, reducing the competitiveness of Latvian entrepreneurs in terms of costs (see Fig. 2).

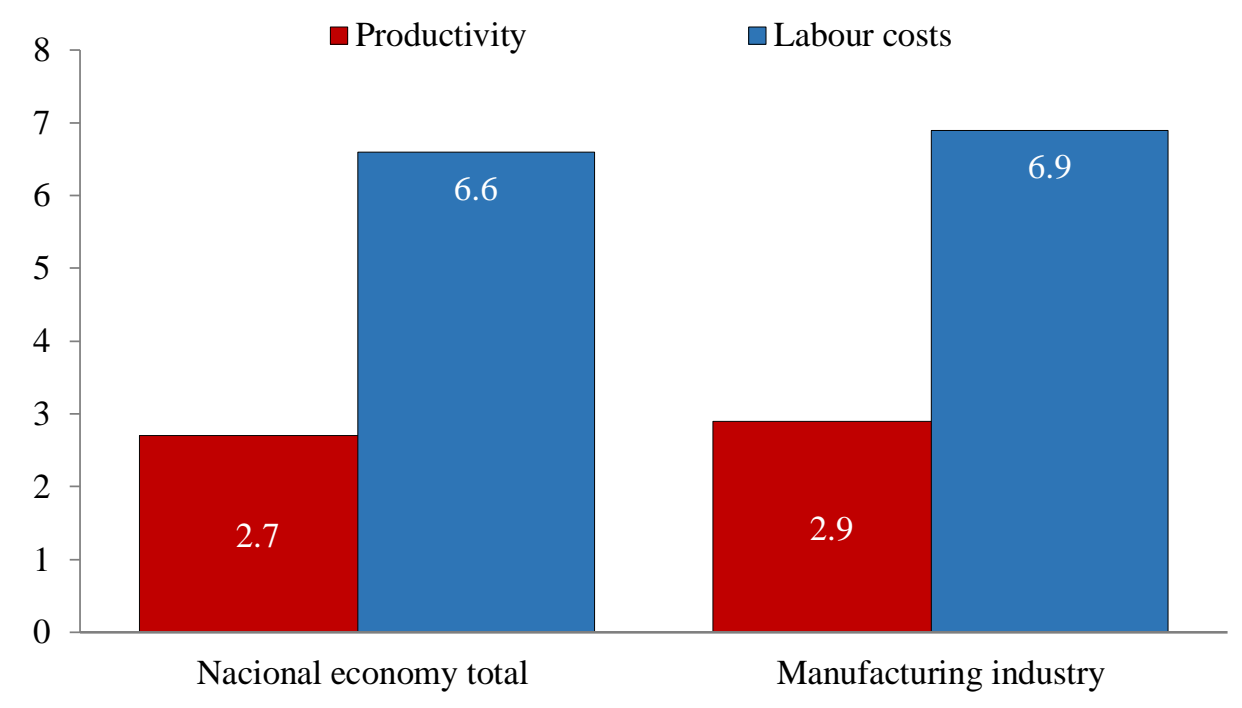

\section{Fig.2. Productivity and labour costs in Latvia from 2011 until 2017 (average increase per year in \%)}

Source: constructed by the author using [3]

The increase in product unit labour costs (ULC) also evidences of the risks of losses in cost competitiveness. From 2013 to 2017, productivity rose almost 3 times faster than wages, and nominal ULC increased by almost $5 \%$ per year on average [2, p.81-82]. Wage is a significant cost competitiveness factor; therefore, its rise should be balanced with a rise in productivity. Otherwise, the competitiveness in tradable sectors is lost, which does not result in a stable growth of income and welfare. Slow productivity growth in comparison with the growth of labour and other production costs leads to price increase of final consumer goods and services, which negatively affect producers' competitiveness and it leads to the decline in market share.

In Latvia, as well as in other Baltic states, the dynamics of price competitiveness (GDP deflator based REER) are growing slower than the cost competitiveness indicator (ULC-based REER) evidencing that the rise in labour costs affected the reduction in the cost-to-price ratio rather than are compensated completely in the rise in prices. This means that the increase in labour costs, which is not compensated by a corresponding rise in productivity, may have a negative effect on the share of company's profits, which entrepreneurs will be forced to adjust to keep price competitiveness in external markets. Trends in recent years show that as economic activities are growing, price and cost competitiveness indicators get worse, and wage convergence is one the most important factors here.

Re-invigorating productivity growth will be the key to keeping Latvian entrepreneurs competitive and getting more quickly to a higher standard of living. Technological factors such as the modernisation of production, the development of existing technologies and the deployment of new technologies are essential to increasing productivity levels. The transition from old to newer technologies contributes to productivity gains at company and industry levels. However, the performance of such changes in increasing aggregate productivity levels depends on reallocation of resources from lower to higher productivity activities as well as on activities with higher productivity dynamics. 


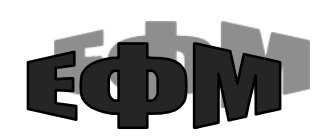

http://efm.vsau.org/

Only by allocating resources to the production of higher value added products at the enterprise level and by reorienting the economic structure towards high added-value sectors, there will be increase productivity and welfare level. Such changes in a market economy (free competition) should take place in the natural way and should be called "creative destruction", but there are a number of factors in reality, which slows these processes, for example unfair competition, administrative obstacles, etc. The process of reallocating resources also depends on the quality of the institutional framework (legislation, state aid, economic and political institutions), which ensure the efficient functioning of the markets for products and resources by minimizing the costs of the redistribution process and the risks, thereby reinforcing the country's competitive advantage. It is also important that entrepreneurs have an interest in changing the existing business model and investing in the development of new technologies and staff. This is crucial in a situation where labour force availability is exacerbated by the deteriorating demographic situation. Thus, in order to increase productivity in Latvia, attention must be paid not so much how to produce but to produce by moving "up the technology ladder". According to data (see Fig. 3), at the moment Latvia is lagging behind both in high and low technology sectors.

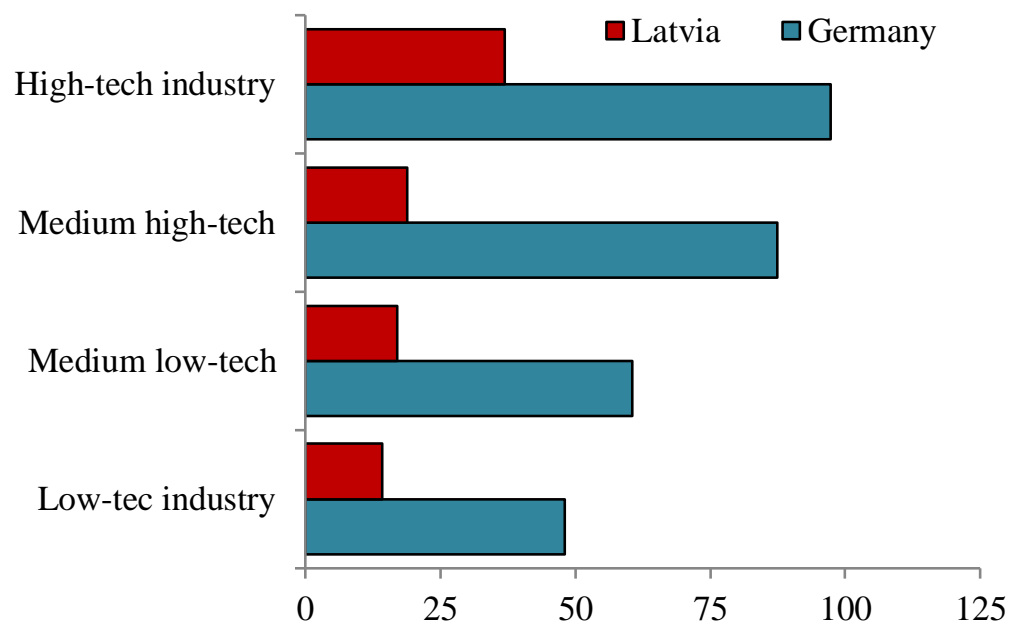

Fig. 3. Productivity in manufacturing industries by technological intensity (thousands EUR per one employee)

Source: constructed by the author using [3]

As shown in Figure 3, the greatest lag behind is observed exactly in medium-high and medium-low sector groups, but in high technology sectors productivity level differences are not so large. Thus, it is possible to conclude that mitigation of the productivity gap in medium-low and medium-high technology sectors will give significant positive impact on the increase of the total productivity level, however it will not strengthen competitiveness of Latvian producers and will not promote development of production potential in a long-term. It means that in order to increase the total productivity level it is important both to identify problems of certain sectors (study of obstacles on a level of certain enterprises and sectors) and promote structural transformation in economics (progress towards high technology sectors). If low productivity stability continues to persist, it can significantly limit Latvia's growth and competitiveness increases.

Conclusions. In the last 5 years the productivity of Latvia's economy has been at the level of $45 \%$ of the EU average. Although in recent years productivity growth rate was faster than the EU average, but labour costs grew almost twice the rate and this can adversely affect competitiveness of Latvia. A further increase in labour costs is inevitable in the open labour 


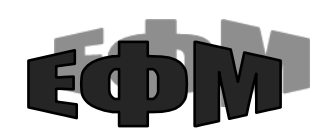

http://efm.vsau.org/

market conditions, therefore, strengthening the competitiveness of Latvian is largely determined by the ability to reduce the productivity gap with the advanced economies. To increase the total productivity level in Latvia it is important to both identify problems of certain sectors (study of obstacles on a level of certain enterprises and sectors) and promote structural transformation in economics (progress towards high technology sectors).

One of the most significant productivity challenges in Latvia is the need to strengthen the production capacity and capacity of the industrial sector, in order to be able to adapt to the challenges of the new industrial age by encouraging investment in new technologies. Therefore, it is important to understand whether we are prepared for the new challenges of competitiveness, i.e. whether we are able to benefit from future production opportunities.

\title{
References
}

1. Brill M., Holman C., Morris C., Raichoudhary R. (2017). Understanding the Labor Productivity and Compensation Gap. Beyond the Numbers: Productivity, U.S. Bureau of Labor Statistics, vol. 6, no. 6, 14 p.

2. Economic Development of Latvia 2018, Ministry of Economics Republic of Latvia, Rīga, 2018, 154 p.

3. Eurostat, 2019. Statistic Database. [Online] Available at: http://ec.europa.eu/eurostat/data/database.

4. Jekabsone S., Skribane I., Priede J., Skapars R. (2017). Productivity and its Impact on the Competitiveness of Latvia. European Research Studies Journal, Vol. 20, No. 3A, p. 920930.

5. Jekabsone S., Skribane I. (2018). Productivity Trap in Latvia, European Integration Studies, No.12, p. 92-103.

6. Measuring Productivity - OECD Manual: Measurement of Aggregate and IndustryLevel Productivity Growth, 2001. OECD, Paris, 156 p.

7. Priede, J., \& Pereira, E. T. (2015). European Union's Competitiveness and Export Performance in Context of EU - Russia Political and Economic Sanctions. Procedia - Social and Behavioral Sciences, 207, p. 680-689.

8. Readiness for the Future of Production Report 2018, World Economic Forum, 2018, 266 p.

9. Regulation, institutions and productivity. New macroeconomic evidence from OECD countries, 2017. OECD, Paris: Economics department working papers, No. 1393, 28 p.

10. The Global Competitiveness Report 2018, WEF, 2018, 671 p.

\section{АНОТАЦІЯ \\ ПРОБЛЕМИ ПРОДУКТИВНОСТІ ТА КОНКУРЕНТОСПРОМОЖНОСТІ ЛАТВІЇ В КОНТЕКСТІ ГЛОБАЛЬНОЇ ЕКОНОМІКИ}

\author{
ДЖЕКАБСОНЕ Сандра, \\ доктор економічних наук, \\ професор кафедри економіки, \\ Латвійський університет \\ (м. Рига)
}

У статті проаналізовано динаміку продуктивності праці в Латвії та виявлено фактори, які вплинули на продуктивність праці за останні 5 років, 3 метою порівняння продуктивності праці в Латвії з середнім показником по ЄС. Аналізуючи зміни продуктивності і витрат на робочу силу в Латвії з 2013 по 2017 рік, видно, що зростання витрат на робочу силу перевищує зростання продуктивності більш ніж у 2 рази як в 
http://efm.vsau.org/

торговельному секторі, так і в економіці загалом. Повільне зростання продуктивності, в порівнянні з витратами на робочу силу та іншими виробничими витратами, призводить до зростання цін на кінцеві товари i послуги, що негативно впливає на конкурентоспроможність виробників як на внутрішньому, так і на зовнішньому ринку. Також у статті зосереджено увагу на підвищенні конкурентоспроможності економіки Латвії. Однією з головних проблем Латвії $є$ створення нових конкурентних переваг, пов'язаних 3 інвестиціями в новітні технології, інновації, дослідження, людський капітал, ефективний розподіл ресурсів і перерозподіл, що пов'язано зі змінами поведінки економічних суб'єктів. У результаті дослідження виявлено, що підвищення рівня продуктивності визначають два взаємопов'язані процеси. По-перше, це залежить від вибору підприємцями переваг, на яких засновані їхні бізнес-стратегії, що визначають напрями управління бізнесом і технологічні рішення. По-друге, це здатність країни забезпечити перерозподіл ресурсів до найбільш продуктивних фірм і секторів, тобто сприяти структурним реформам або «технологічній модернізації».

Ключові слова: продуктивність праці, витрати на робочу силу, виробничі витрати, економічне зростання, конкурентоспроможність.

Рис.: 3. Літ.: 10.

\title{
АННОТАЦИЯ \\ ПРОБЛЕМЫ ПРОИЗВОДИТЕЛЬНОСТИ И КОНКУРЕНТОСПОСОБНОСТИ ЛАТВИИ В КОНТЕКСТЕ ГЛОБАЛЬНОЙ ЭКОНОМИКИ
}

\author{
ДЖЕКАБСОНЕ Сандра, \\ доктор экономических наук, \\ профессор кафедры экономики, \\ Латвийский университет
}

(2. Puza)

В статье проанализирована динамика производительности труда в Латвии и выявлены факторы, которые повлияли на производительность труда в последние 5 лет, с целью сравнения производительности труда в Латвии со средним показателем по ЕС. Анализируя изменения производительности и затрат на рабочую силу в Латвии с 2013 по 2017 год, видно, что рост затрат на рабочую силу превышает рост производительности более чем в 2 раза как в секторе торговли, так и в экономике целом. Медленный рост производительности по сравнению с затратами на рабочую силу и другими производственными затратами приводит к росту цен на конечные товары и услуги, что отрицательно влияет на конкурентоспособность производителей как на внутреннем, так и на внешнем рынке. Также в статье сосредоточено внимание на повышении конкурентоспособности экономики Латвии. Одной из главных проблем Латвии является создание новых конкурентных преимуществ, связанных с инвестициями в новейшие технологии, инновации, исследования, человеческий капитал, эффективное распределение ресурсов и перераспределения, что связано с изменениями поведения экономических субъектов.

В результате исследования выяснено, что повышение уровня производительности определяют два взаимосвязанных процесса. Во-первых, это зависит от выбора предпринимателями преимуществ, на которых основаны их бизнес-стратегии, определяющие направления управления бизнесом и технологические решения. Вовторых, это способность страны обеспечить перераспределение ресурсов к наиболее 
продуктивным фирмам и секторам, т.е. содействовать структурным реформам или «технологической модернизации».

Ключевые слова: производительность труда, затраты на рабочую силу, производственные затраты, экономический рост, конкурентоспособность.

Рис.: 3. Лит.: 10.

\section{Відомості про автора}

JEKABSONE Sandra - Doctor of Economics, Professor of the Department of Economics, Faculty of Business, Management and Economics, University of Latvia (LV1050, Riga, Aspazijas blv.5, room 330, e-mail: sandra.jekabsone@lu.lv).

ДЖЭКАБСОНЕ Сандра - доктор экономических наук, профессор кафедры экономики, факультет бизнеса, менеджмента и экономики, Латвийский университет (LV1050, Рига, булв. Аспазияс 5, e-mail: sandra.jekabsone@lu.lv).

ДЖЕКАБСОНЕ Сандра - доктор економічних наук, професор кафедри економіки факультету бізнесу, менеджменту та економіки, Латвійський університет (LV1050, Рига, булв. Аспазіяс 5, e-mail: sandra.jekabsone @lu.lv). 